\title{
Economic Growth and Exporting Activity: An Empirical Analysis on Greek Industry
}

\author{
Ilias A. Makris ${ }^{1}$, Vasilis Nikolaidis ${ }^{2}$, Stavros Stavroyiannis ${ }^{3}$
}

\begin{abstract}
:
The aim of the present paper is to locate and analyse the factors affecting firms' economic behaviour in food products' sector, by collecting data from a large number of firms and indicators.

A special focus concerning exporting activity took place, trying to disclose the factors that spur exports, as they are considered to be a synonym of economic growth and prosperity. Several methodological issues of exports' valuation were opposed and some strong conclusions were underlined as regard to the necessary infrastructure that a firm should develop, in order to grow, and to establish a dynamic exporting profile.
\end{abstract}

${ }^{1}$ Ilias A. Makris, Assistant Professor,

Dept. of Finance and Auditing, Technological Education Institute, of Kalamata Greece,

Address: Melanipou 6 str., Patras, Greece, Postal Code: 26443

Tel.: 6973-584628,e-mail: elimak99@yahoo.com

${ }^{2}$ Lecturer, Dept. of Finance and Auditing,

Technological Education Institute of Kalamata, Greece

${ }^{3}$ Professor, Dept. of Finance and Auditing,

Technological Education Institute of Kalamata, Greece 


\section{Introduction}

Food products' sector is the most populated sector in European economy, concerning sales and employment, with positive trade balance in EU-25. Concerning Greece, the sector presents high potentials and still seems to have a strong competitive advantage due to the large agricultural production. Almost twenty per cent of the manufacturing firms are activated in the sector, contributing highly to all basic economic indices and employment.

However, the vast majority of the firms is rather small compared to their international competitors, presenting low investment activity (fixed assets), decrease in overall production and poor innovative activity. Adversely to the European status (EU-25), trade deficit in food products' sector has increased by $79.4 \%$ between 2002-2004, due to the high volume of imports relative to exports (three times up in the period 1998-2005), with minor improvement the last years (IOBE 2007, 2009) ${ }^{4}$. As the sector is crucial for the overall economy and the most important problem confronted seems to be the lack of competitive advantage relative to competitors (mainly European countries), it is important to highlight the factors that may lead to increasing exporting activity and economic performance.

\section{Factors Affecting Growth of the Firm}

The analysis of the growth of a firm is a rather subjective issue that can be measured by different indices and methods. A rather indicative value is the growth in gross sales, as it implies market dynamism, increased share and strong competitive advantage, that may indicates high profitability (if the production cost is low). As for the factors affecting growth, a variety of variables have been used by many surveys; Increased volume of fixed assets is considered to be a source of motive power for firms, increasing long-run growth and employment (Chirinko, 1993; Voulgaris et al., 2005) and affect positively cash flow and profitability (Eriotis et al., 2002; Agiomirgiannakis et al., 2006).

Innovative activity through the expenses for Research and Development (R\&D), or by acquiring of know-how (intellectual property rights), seems also to affect growth and economic performance (Kafouros, 2005; Delapierre et al., 1998; Ferguson and Olofsson, 2004; Autio and Parhankangas, 1998; Makris, 2007). Furthermore, firm's size and age seem to contribute to economic growth, either positively (Agiomiriannakis et al., 2006, and Voulgaris et al., 2005), or negatively (Voudouris et al., 2000; Giudici and Paleari, 2000; Bartjokas, 2001; Thalassinos et al., 2012; Thalassinos and Politis, 2012).

\footnotetext{
${ }^{4}$ IOBE: Foundation for Economic and Industrial Research (a private, non-profit, publicbenefit research organisation).
} 
Some additional factors that are referred in literature as explanatory variables of growth, are profitability, location of the plant (urban rural etc.), whether is a listed firm or not and the existence (or not) of a quality certification (ISO etc.) as it seems to affect positively sales, especially in foreign markets.

The most admitted factor however, spurring economic growth and income (private and national), is exporting activity. Its' contribution to increased productivity, and market dynamism has been underlined thoroughly by many researchers, both in national level (Liargovas and Scandalis, 2008, Greenaway and Kneller, 2005), and in the level of the firm (Roberts and Tybout, 1997; Bernard and Jensen, 2001; Bernard and Wagner, 1997 and 20015; Aw et al., 1998, Greenaway and Yu, 2004; Arnold and Hussinger, 2005) ${ }^{6}$.

Exporting activity seems also to generate higher employment growth, faster growth of shipments, diversification of risk, increased innovation and improved survival chances relative to non-exporters with similar characteristics (Basile, 2001). Furthermore, firms deeply involved in exporting activity, are likely to benefit from their international contacts, accumulating knowledge and technology at faster rates, and achieving higher capacity utilization, and exploitation of economies of scale (Castellani, 2002; Bernard and Jensen, 1999, Aitken et al., 1997; Sjoholm, 1999; Liapis et al., 2013). Buch et al. (2009) also, underlined that export openness is associated with lower firm-level volatility of real sales.

\section{Data, Methodology and Findings}

To create our sample, we used micro-level data of firms operating in Food products' industry. We collected data from 335 firms randomly selected, between 2001 and $2005^{7}$. Variables were formed from published, economic and non-economic, data and are listed in Table 1. The total number of variables recorded for each firm was 11. For those variables we examine their contribution in Gross sales' growth, choosing firstly to perform a simple correlation matrix, using Spearman's rho test, as it is considered to fit better for non-parametric data sets (like many of the variables used).

From the results that are summarized in Table 2, it seems that a significant correlation exists between gross sales, and exports, fixed assets' growth, innovation, size, assets, net profits, and quality's certification. Most of them are prospected, as their interaction is also verified by surveys from other countries and sectors,

\footnotetext{
${ }^{5}$ All summarized in Castellani 2002

${ }^{6}$ Although there are also few surveys, concluding in ambiguous results as regard to the effect of exports to long-run performance (see for example, Clerides et al, 1998).

${ }^{7}$ ICAP's Greek Financial Directory was used, a private database including balance sheets of the vast majority of firms operating in the economy (www.icap.gr), along with firms' balance sheets, that were further examined.
} 
however, with rather low coefficients' value. The interesting point is that larger firms (either concerning employment or assets) seem to achieve better results, although SMEs are considered to have more dynamism.

Table 1: Variables used in the analysis

\begin{tabular}{|c|c|c|}
\hline & \multicolumn{2}{|l|}{ Dependent Variable } \\
\hline 1 & D_GS & $\begin{array}{l}\text { Difference in gross sales between } 2001 \text { and } 2005 \text { (above or } \\
\text { below sample's average-binary) }\end{array}$ \\
\hline & \multicolumn{2}{|c|}{ Independent Variables } \\
\hline 2 & Age & Age of firm (years-continuous). \\
\hline 3 & Location & Indicates location type (1=capital, $2=$ urban, $3=$ rural $)$ \\
\hline 4 & Exports & Indicates exporting status (percentage - continuous) \\
\hline 5 & ASE & $\begin{array}{l}\text { Whether the firm is listed or not in (Athens) Stock Market } \\
\text { (binary) }\end{array}$ \\
\hline 6 & R\&D (innovation) & $\begin{array}{l}\text { Expenses for Research and Development and IPRs' (implying } \\
\text { innovative activity-binary) }\end{array}$ \\
\hline 7 & $\begin{array}{l}\text { Size } \\
\text { (Employment) }\end{array}$ & Number of Employees (in 2005-continuous) \\
\hline 8 & Assets & Total Assets in 2005 (implying firms magnitude) \\
\hline 9 & ISO & Whether e a quality's certification exists or not (Binary) \\
\hline 10 & Net Profits & $\begin{array}{l}\text { Firm's net profits in } 2005 \text { (implying efficient production } \\
\text { process, low cost, and economic prosperity- continuous) }\end{array}$ \\
\hline 11 & D_FA & $\begin{array}{l}\text { Difference of investment in fixed assets between } 2001 \text { and } \\
2005 \text { (fixed assets'difference-sample's average difference- } \\
\text { continuous) }\end{array}$ \\
\hline
\end{tabular}

Table 2: Correlation matrix (summarised results) Spearman's rho

\begin{tabular}{|c|c|c|}
\hline \multicolumn{2}{|l|}{ Spearman's rho } & \multirow[b]{2}{*}{$\begin{array}{r}.160 * * \\
.003\end{array}$} \\
\hline Exports & $\begin{array}{l}\text { Correlation Coefficient } \\
\text { Sig. (2-tailed) }\end{array}$ & \\
\hline Location & $\begin{array}{l}\text { Correlation Coefficient } \\
\text { Sig. (2-tailed) }\end{array}$ & $\begin{array}{r}-.009 \\
.863\end{array}$ \\
\hline R\&D (Innovation) & $\begin{array}{l}\text { Correlation Coefficient } \\
\text { Sig. (2-tailed) }\end{array}$ & $\begin{array}{r}.159 * * \\
.003\end{array}$ \\
\hline D_FA & $\begin{array}{l}\text { Correlation Coefficient } \\
\text { Sig. (2-tailed) }\end{array}$ & $\begin{array}{r}.177^{* *} \\
.001\end{array}$ \\
\hline Age & $\begin{array}{l}\text { Correlation Coefficient } \\
\text { Sig. (2-tailed) }\end{array}$ & $\begin{array}{r}-.067 \\
.220\end{array}$ \\
\hline$\overline{\mathrm{ASE}}$ & $\begin{array}{l}\text { Correlation Coefficient } \\
\text { Sig. (2-tailed) }\end{array}$ & $\begin{array}{l}.101 \\
.064\end{array}$ \\
\hline ISO & $\begin{array}{l}\text { Correlation Coefficient } \\
\text { Sig. (2-tailed) }\end{array}$ & $\begin{array}{r}.149^{* *} \\
.006\end{array}$ \\
\hline SIZE & Correlation Coefficient & $.183^{* *}$ \\
\hline
\end{tabular}




\begin{tabular}{|c|c|c|}
\hline & Sig. (2-tailed) & .001 \\
\hline ASSETS & $\begin{array}{l}\text { Correlation Coefficient } \\
\text { Sig. (2-tailed) }\end{array}$ & $\begin{array}{r}.157 * * \\
.004\end{array}$ \\
\hline Net Profits & $\begin{array}{l}\text { Correlation Coefficient } \\
\text { Sig. (2-tailed) }\end{array}$ & $\begin{array}{r}.247 * * \\
.000\end{array}$ \\
\hline $\mathrm{N}=335$ & & \\
\hline
\end{tabular}

The answer to that may be the fact that we analyse a rather traditional sector, with older and thus, larger firms, operating in. Exports' low coefficient is also quite interested and need to be further analysed. In order to verify our findings, we proceed to econometric analysis too, through the use of logistic regression, as it is suitable for binary variables. The results are summarised in Tables 3-5 (we have excluded net profits, to avoid possible bias due to strong direct relation with sales).

The explanatory capability of the model, is not too high, however nearly $70 \%$ of all cases are classified correctly. The only thing that should be underlined is the not so good predictability of the 1 case (gross sales' difference above sample's average).

The $\operatorname{Exp}(B)$ coefficient, shows that Innovation appeared to affect most economic growth, with products' quality certification, exports and growth in investment activity (D_FA) to follow. Adversely to correlation's result, size (either as Assets or Employment) does not seem to affect significantly sales' growth. On the contrary, exports not only affect positively them, but also, appear the higher significance of all variables.

Thus, they seem to be a factor of major importance for the firm and the whole economy, especially in such a sector that Greece still seems to have the competitive advantage. In the rest of the paper, we will focus to exports, locating the variables that affect them.

Tables 3-5: Model's Summary, Classification Table and results

Table 3: Model Summary

\begin{tabular}{|l|r|r|r|}
\hline Step & -2 Log likelihood & Cox \& Snell R Square & \multicolumn{2}{|c|}{ Nagelkerke R Square } \\
\hline 1 & $416.842(a)$ & .099 & .134 \\
\hline
\end{tabular}

a Estimation terminated at iteration number 4 because parameter estimates changed by less than .001. 
Table 4: Classification Table(a)

\begin{tabular}{|c|c|c|c|c|c|}
\hline & & & \multicolumn{3}{|c|}{ Predicted } \\
\hline & & & \multicolumn{2}{|c|}{ D_GS } & \multirow[t]{2}{*}{ Percentage Correct } \\
\hline \multicolumn{3}{|c|}{ Observed } & .00 & 1.00 & \\
\hline \multirow[t]{3}{*}{ Step 1} & D_GS & .00 & 168 & 32 & 84.0 \\
\hline & & 1.00 & 78 & 57 & 42.2 \\
\hline & Overa & & & & 67.2 \\
\hline
\end{tabular}

a The cut value is 500.

Table 5: Variables in the Equation

\begin{tabular}{|ll|r|r|r|r|r|r|}
\hline & & \multicolumn{1}{|c|}{ B } & \multicolumn{1}{c|}{ S.E. } & Wald & df & \multicolumn{1}{c|}{ Sig. } & Exp(B) \\
\hline Step & Exports & .010 & .004 & 7.302 & 1 & .007 & 1.010 \\
$1(\mathrm{a})$ & & -.054 & .147 & .132 & 1 & .717 & .948 \\
& Location & .000 & .000 & .100 & 1 & .752 & 1.000 \\
& Assets & .735 & .309 & 5.681 & 1 & .017 & 2.086 \\
& R\&D & -.005 & .006 & .538 & 1 & .463 & .995 \\
& AGE & .748 & .598 & 1.567 & 1 & .211 & 2.113 \\
& ASE & -.001 & .001 & .237 & 1 & .627 & .999 \\
& SIZE & .418 & .249 & 2.806 & 1 & .094 & 1.518 \\
& ISO & .002 & .001 & 6.101 & 1 & .014 & 1.002 \\
& D_FA & -.812 & .380 & 4.570 & 1 & .033 & .444 \\
\hline
\end{tabular}

a Variable(s) entered on step 1: Exports, Location, Assets, R\&D, AGE, ASE, SIZE, ISO, D_FA.

\section{Exporting Activity and Economic Growth}

Figure 1 presents a classification of sample's exporting ratio (using a 10\% cut-off). As we can see, the population of firms becomes smaller when approaching ratio of $40-60 \%$, and it is increased for higher exporting activity, a picture similar to that of Nikolaidis et al (2009), in a survey concerning various Greek industrial sectors. Furthermore, the vast majority of the firms seem to be concentrated in the categories 0 (non-exporting) and 1-10\% (low exporting).

A critical question seems thus, to emerge; are all those firms presenting 1-10\% exporting ratio, exporters? When a firm should be characterized as dynamic exporting company? Which are the main characteristics and the necessary infrastructure, in order for a firm, to develop a dynamic exporting base in order to survive and grow? Trying to answer that, we have to locate and analyse the factors that appear to affect exporting activity. 
Figure 1: Distribution of companies vs. export performance (\%)

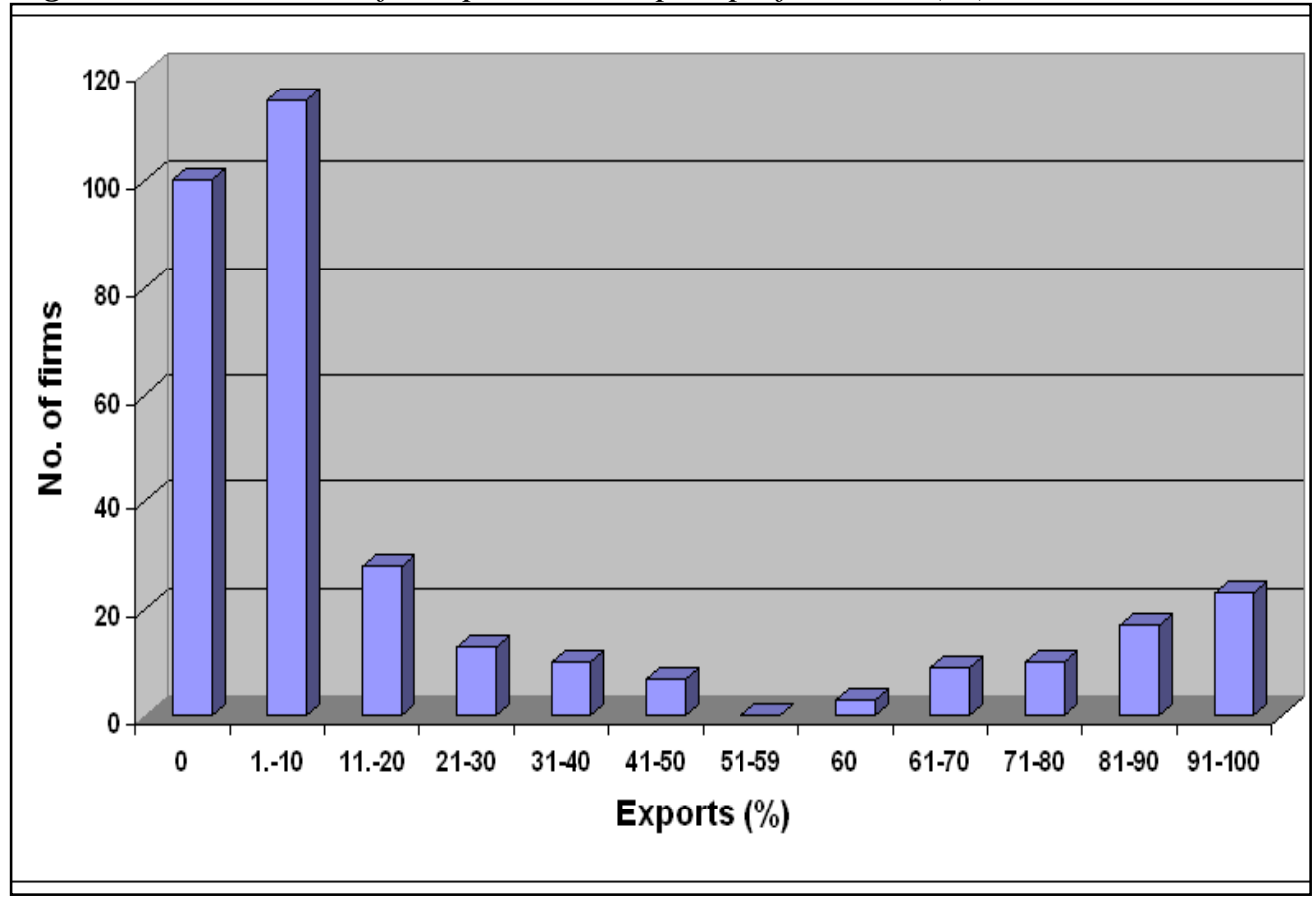

Bleaney and Wakelin (2002) claimed that R\&D expenditures are positively correlated with exports. Filatotchev et al (2009) also, found a positive effect of innovative activity on exporting performance, underlining that, firms, wishing to export, should first reach an initial level of R\&D, while similar are the conclusion of Cavusgil (1984).

Size of the firm and profitability seems also to be correlated with exporting activity, with Bernard and Jensen (1999) and Greenaway and Kneller (2005), to underline that larger and more profitable firms achieve higher exports. Lawless (2009), conclude that firms with greater (foreign) market coverage, tend to be larger in terms of employment and Castellani (2002) underlines that firm size and location (advanced areas, domestic, rural etc) affects exporting ratio, with large domestic markets to be more effective. On the other hand, surveys with mixed empirical findings, also exist; Greenaway and Yu (2004), found that exporters are smaller than non-exporters, by 10-15 per cent (but more efficient) and Cavusgil (1984), claimed that firm size is a proxy for various advantages associated with size and not a factor that spur exporting activity. We also expect quality of products and firm's age to affect exporting process.

A rather debated issue concerning the inclusion of exports in economic analysis however is the methodology followed. That is mainly due to the difficulty to be quantified with accuracy, as their exact ratio cannot be specified from officially 
published data (the same happens concerning difference in exports among years), and we can consider only what firms declare. Thus several problems exist by treating exports as a continuous variable. As a result, most surveys, either proceed to subjective calculations, or mainly, treat exports as binary variable (exporting, nonexporting).

However, again, the methodology followed by researchers is rather differentiated. Many surveys classify exports as 1 (=exports) and 0 (=non exports) ${ }^{8}$. On the other hand, Bernard and Jensen (1999) and Bernard and Wagner (1997, in Castellani 2002) in their surveys, measured exports status by a binary variable too, adding however some other characteristics as dummy variables, in order to succeed better results. Arnold and Hussinger (2005) also, used a similar process discriminating exporters from non-exporters, using as a cut-off value the ratio of 5\% (exports over total sales).

The rather logical justification, was that a rather low exporting ratio, can neither be considered as active exporting activity, nor characterise a firm as exporter. Such ratios $(3 \%, 5 \%$ etc.), may only imply cooperation with a small familiar firm (or individual) in another neighbouring country (e.g. Greece and another country of Balkans, etc.). To a recent survey also, Buch et al. (2009), measuring the intensive and extensive margin of firm-level export activity, used both binary dummy variables indicating the exporters status, along with continuous variable (exports over sales), resulting in quite different findings for each one.

On the other hand, Cuvasgil (1984) claimed that treated exports as a binary variable, is not a good idea, as there are several distinct types of exporters, each with a varying managerial and organizational profile. Thus, the existence of a 'typical' exporting firm may be an oversimplification, and a dichotomous classification of exporting firms into least and most active exporters may be misleading. Instead, firms should rather be viewed on a continuous ranging from least to most active exporters. Lawless (2009), trying to overcome such problems, used a completely different classification, analogous to the number of markets that a firm export to (market coverage).

From the above is obvious that there are methodological problems of using exports in economic analysis. So, what is the proper methodology of treating exports? So far we have included them in our analysis as continuous variable, although rather subjective as already mentioned. In this part of the survey, we try to succeed the better coverage of that issue, trying to locate the factors that are related with exporting activity, with the use of four different types of binary expression of exports (following literature too); i) A typical binary form ( $0=$ =non-exporting, $1=$ exporting), and three modified binary forms, considering as non-exporting, firms

\footnotetext{
${ }^{8}$ See indicatively, Agiomirianakis et al (2006), Liargovas and Scandalis (2008), Baldin and Gu (2003), Bleaney and Wakelin (2002), Filatotchev et al (2009), etc.
} 
that declared exports less than $5 \%$ of sales ratio (ii), less than $10 \%$ (iii) and less than $15 \%$ (iv). The method selected was again logistic regression (as each dependent variable is binary), and four different models were used, each one with different dependent variable. We have also tried to separate listed firms, in order to locate possible differences relative to others.

Findings are summarized in Table 6 and seem to be rather ambiguous, as using different forms of measuring exporting activity, we find quite different results. That seems to enhance our assumption (underlined by literature too) about the methodological problems of handling exports and especially what can be considered as active exporting activity. However, some strong conclusions can be underlined. First of all, the second model (non-exporting=0-5\%), appears to have the higher predictability, with first model (non-exporting $=0 \%$ ), to follow.

That classification is in accordance with the classification of Arnold and Hussinger (2005), verifying that a very small ratio of exports, obviously cannot be characterized as true exporting activity. Furthermore, as the width of non-exporting measurement broaden $(0=0-10 \%$ and $0-15 \%)$, the predictability of the model become extremely high concerning the zero cases, while is too low for the one cases.

That is possibly an indication of a vague exporting profile of Greek firms. The latter, if true, is rather discouraging, as if specific exporting characteristics do not exist, it is difficult for a firm to try to develop a dynamic infrastructure following specific routines and patterns, in order to survive and grow.

Table 6: Summarized results of Logistic regression's Processes

\begin{tabular}{|c|c|c|c|c|c|c|c|}
\hline \multicolumn{2}{|c|}{$\begin{array}{c}\text { Exports }(1) \\
(0=0 \%, 1=1-100 \%)\end{array}$} & \multicolumn{2}{|c|}{$\begin{array}{c}\text { Exports }(2)(0=0-5 \%, 1=6- \\
100 \%)\end{array}$} & \multicolumn{2}{|c|}{$\begin{array}{c}\text { Exports (3) } \\
(0=0-10 \%, 1=11- \\
100 \%)\end{array}$} & \multicolumn{2}{|c|}{$\begin{array}{c}\text { Exports }(4) \\
(0=0-15 \%, 1=16- \\
100 \%)\end{array}$} \\
\hline $\begin{array}{l}\text { Nagelk } \\
\text { erke R } \\
\text { Square }\end{array}$ & .259 & $\begin{array}{l}\text { Nagelkerke } \\
\text { R Square }\end{array}$ & .126 & $\begin{array}{l}\text { Nagelkerke } \\
\text { R Square }\end{array}$ & .126 & $\begin{array}{l}\text { Nagelkerke } \\
\text { R Square }\end{array}$ & .118 \\
\hline $\begin{array}{l}\text { Percent } \\
\text { age } \\
\text { Correct }\end{array}$ & $\begin{array}{l}75.2(0: \\
31.0 \\
94.0)\end{array}$ & $\begin{array}{l}\text { Percentage } \\
\text { Correct }\end{array}$ & $\begin{array}{l}67.5(0: \\
72.4 \\
62.1)\end{array}$ & $\begin{array}{l}\text { Percentage } \\
\text { Correct }\end{array}$ & $\begin{array}{l}63.3(0: \\
84.7 \\
25.0)\end{array}$ & $\begin{array}{l}\text { Percentage } \\
\text { Correct }\end{array}$ & $\begin{array}{l}67.8 \\
(0: \\
92.1 \\
1: \\
15.9)\end{array}$ \\
\hline $\begin{array}{l}\text { Locatio } \\
\text { n (sig.) }\end{array}$ & $\begin{array}{l}.709 \\
(\operatorname{Exp}(B): 1 . \\
061)\end{array}$ & $\begin{array}{l}\text { Location } \\
\text { (sig.) }\end{array}$ & $\begin{array}{l}.158 \\
(\operatorname{Exp}(\mathrm{B}): 1 . \\
221)\end{array}$ & $\begin{array}{l}\text { Location } \\
\text { (sig.) }\end{array}$ & $\begin{array}{l}.042 \\
(\operatorname{Exp}(\mathrm{B}) \\
: 1.348)\end{array}$ & $\begin{array}{l}\text { Location } \\
\text { (sig.) }\end{array}$ & $\begin{array}{l}.013 \\
(\operatorname{Exp}( \\
\text { B):1.4 } \\
50)\end{array}$ \\
\hline $\begin{array}{l}\text { Assets } \\
\text { (sig.) }\end{array}$ & $\begin{array}{l}.001 \\
(\operatorname{Exp}(B): 1 . \\
002)\end{array}$ & Assets (sig.) & $\begin{array}{l}.840 \\
(\operatorname{Exp}(\mathrm{B}): 1 \\
000)\end{array}$ & $\begin{array}{l}\text { Assets } \\
\text { (sig.) }\end{array}$ & $\begin{array}{l}.085 \\
(\operatorname{Exp}(\mathrm{B}) \\
: 1.000)\end{array}$ & $\begin{array}{l}\text { Assets } \\
\text { (sig.) }\end{array}$ & $\begin{array}{l}.093 \\
(\operatorname{Exp}( \\
\text { B): } 1.0 \\
00)\end{array}$ \\
\hline Net & .394 & Net Profits & .399 & Net Profits & .220 & Net Profits & .122 \\
\hline
\end{tabular}




\begin{tabular}{|c|c|c|c|c|c|c|c|}
\hline $\begin{array}{l}\text { Profits } \\
\text { (sig.) }\end{array}$ & $\begin{array}{l}(\operatorname{Exp}(\mathrm{B}): 1 . \\
000)\end{array}$ & (sig.) & $\begin{array}{l}(\operatorname{Exp}(\mathrm{B}): 1, \\
000)\end{array}$ & (sig.) & $\begin{array}{l}(\operatorname{Exp}(\mathrm{B}) \\
: 1.000)\end{array}$ & (sig.) & $\begin{array}{l}(\operatorname{Exp}( \\
B): 1.0 \\
00)\end{array}$ \\
\hline $\begin{array}{l}\text { R\&D } \\
\text { (sig.) }\end{array}$ & $\begin{array}{l}.027 \\
(\operatorname{Exp}(B): 2 . \\
705)\end{array}$ & R\&D (sig.) & $\begin{array}{l}.039 \\
(\operatorname{Exp}(\mathrm{B}): 1, \\
924)\end{array}$ & R\&D (sig.) & $\begin{array}{l}.013 \\
(\operatorname{Exp}(B) \\
: 2.186)\end{array}$ & R\&D (sig.) & $\begin{array}{l}.107 \\
(\operatorname{Exp}( \\
B): 1.6 \\
75)\end{array}$ \\
\hline $\begin{array}{l}\text { Age } \\
\text { (sig.) }\end{array}$ & $\begin{array}{l}.315 \\
(\operatorname{Exp}(B): 1 . \\
008)\end{array}$ & Age (sig.) & $\begin{array}{l}.120 \\
(\operatorname{Exp}(\mathrm{B}): 1, \\
010)\end{array}$ & Age (sig.) & $\begin{array}{l}.315 \\
(\operatorname{Exp}(\mathrm{B}) \\
: 1.007)\end{array}$ & Age (sig.) & $\begin{array}{l}.499 \\
(\operatorname{Exp}( \\
B): 1.0 \\
05)\end{array}$ \\
\hline $\begin{array}{l}\text { ASE } \\
\text { (sig.) }\end{array}$ & $\begin{array}{l}\text {,018 } \\
\text { (negative } \\
\text { B) } \\
(\operatorname{Exp}(B): \\
.135)\end{array}$ & ASE (sig.) & $\begin{array}{l}.006 \\
\text { (negative } \\
\text { B) } \\
(\operatorname{Exp}(B):, 1 \\
40)\end{array}$ & ASE (sig.) & $\begin{array}{l}.005 \\
\text { (negativ } \\
\text { e B) } \\
(\operatorname{Exp}(B) \\
: .063)\end{array}$ & ASE (sig.) & $\begin{array}{l}.014 \\
\text { (negati } \\
\text { ve B) } \\
(\operatorname{Exp}( \\
\text { B): } \\
.088)\end{array}$ \\
\hline $\begin{array}{l}\text { Size } \\
\text { (sig.) }\end{array}$ & $\begin{array}{l}, 237 \\
(\operatorname{Exp}(B): .9 \\
97)\end{array}$ & Size (sig.) & $\begin{array}{l}.465 \\
(\operatorname{Exp}(B): 1 . \\
001)\end{array}$ & Size (sig.) & $\begin{array}{l}.035(\mathrm{ne} \\
\text { gative } \\
\mathrm{B}) \\
(\operatorname{Exp}(\mathrm{B}) \\
.996)\end{array}$ & Size (sig.) & $\begin{array}{l}.028(\mathrm{n} \\
\text { egativ } \\
\text { e B) } \\
(\operatorname{Exp}( \\
\text { B): } \\
.995)\end{array}$ \\
\hline $\begin{array}{l}\text { ISO } \\
\text { (sig.) }\end{array}$ & $\begin{array}{l}.055 \\
(\operatorname{Exp}(B): 1 . \\
797)\end{array}$ & ISO (sig.) & $\begin{array}{l}.004 \\
(\operatorname{Exp}(B): 2 . \\
042)\end{array}$ & ISO (sig.) & $\begin{array}{l}.001 \\
(\operatorname{Exp}(\mathrm{B}) \\
: 2.241)\end{array}$ & ISO (sig.) & $\begin{array}{l}.002 \\
(\operatorname{Exp}( \\
B): 2.2 \\
76)\end{array}$ \\
\hline $\begin{array}{l}\text { D_FA } \\
\text { (sig.) }\end{array}$ & $\begin{array}{l}.115 \\
(\operatorname{Exp}(B): .9 \\
99)\end{array}$ & D_FA (sig.) & $\begin{array}{l}.440 \\
(\operatorname{Exp}(B): 1 . \\
000)\end{array}$ & $\begin{array}{l}\text { D_FA } \\
\text { (sig.) }\end{array}$ & $\begin{array}{l}.643 \\
(\operatorname{Exp}(\mathrm{B}) \\
: 1.000)\end{array}$ & $\begin{array}{l}\text { D_FA } \\
\text { (sig.) }\end{array}$ & $\begin{array}{l}.775 \\
(\operatorname{Exp}( \\
B): 1.0 \\
00)\end{array}$ \\
\hline
\end{tabular}

Another strong finding of the analysis is that some variables seem to affect significantly exporting activity, irrelevant to the model and dependent variable used. Those are Quality's certification, existed R\&D process, Assets' magnitude and whether a firm is listed or not in stock market (negative effect).

Thus, it seems that Greek exporting firms from food products' sector are big (Assets), innovative (R\&D), have quality's certification (ISO) for their products and, surprisingly, are not listed in stock market (negative B sign).

The latter is very interesting (as listed firms are large companies with strong infrastructure and networks), and should probably be further analysed in future surveys. The lager contribution in exporting (indicating by $\operatorname{Exp}(\mathrm{B})$ value) appears to come from innovation, and quality, which is prospected according to the literature, and makes prominent, that even the sector analysed is rather traditional, new, high quality's products, are those that will allow the establishment of a dynamic exporting base. 


\section{Conclusions}

In the present survey, we tried to examine the factors affecting firm's growth in food products' sector, focusing mainly to one of the most important; exporting activity.

Our findings underline a strong relation (among others) between sales' growth and exporting performance. Following the literature, we try to isolate exports and discover the factors affecting them. In order to overcome several methodological problems and to be more accurate, in analysing the profile of exporting firms, we used four different binary forms of exports' valuation.

Although findings varied relative to the variable used, some specific factors seem to characterise exporting firms in the sector; they are larger (in terms of assets), innovative, non-listed, with qualitative certification for their products.

Thus, it is obvious that first of all, in order a firm to become a dynamic player in the international market enjoying high rates of growth and profits, should establish the critical size, and most important, to produce innovative and high quality products.

\section{References}

Agiomirgiannakis, G., Voulgaris, F. and Papadogonas, T. 2006. Financial factors affecting profitability and employment growth: the case of Greek manufacturing. Int. J. Financial Services Management, 1, 2/3, 232-242.

Aitken, B. J., Hanson G.H., and Harrison A. E. 1997. Spillovers, Foreign Investment and Export Behavior. Journal of International Economics 43(1), 103-132.

Arnold J.M., and Hussinger K. 2005. Export Behaviour and Firm Productivity in German Manufacturing: A Firm-Level Analysis. Review of World Economics, 141 (2), 219243.

Autio, E. and Parhankangas, A.1998. Employment generation potential of new, technologybased firms during a recessionary period: the case of Finland. Small Business Economics, 11, 113-23.

Aw B.Y., Chen X. and Roberts M.J. 2001. Firm-level Evidence on Productivity Differentials and Turnover in Taiwanese Manufacturing. (NBER).

Baldwin R. and Gu W. 2003. Export-market participation and productivity performance in Canadian manufacturing. Canadian Journal of Economics, 36(3), 634-657.

Bartjokas, A. 2001. Financial markets and technological change: patterns of technological and financial decisions by manufacturing firms in Southern Europe. Discussion Paper Series. (The United Nations University, Institute for New Technologies INTECH).

Basile, R. 2001. Export behaviour of Italian manufacturing firms over the nineties: the role of innovation. Research Policy, 30(8), 1185-1201.

Bernard, A.B. and Jensen, B.J. 1999. Exceptional exporter performance: cause, effect, or both? Journal of International Economics, 47, 1-25.

Bleaney, M. and Wakelin K. 2002. Efficiency, Innovation and Exports. Oxford Bulletin of Economics and Statistics, 64(3), 3-15.

Buch, C.M., Dopke, J. and Strotmann, H. 2009. Does Export Openness Increase Firm-level 
Output Volatility? The World Economy, 32(4), 531-550.

Castellani, D. 2002. Export Behaviour and Productivity Growth: Evidence from Italian Manufacturing Firms. Review of World Economics, 138(4), 605-628.

Cavusgil, S.T. 1984. Organizational Characteristics Associated with Export Activity. Journal of Management Studies, 21(I), 3-22.

Chirinko, S.R. 1993. Business fixed investment spending: modelling strategies, empirical results, and policy implications. Journal of Economic Literature, 31, 1875-1911.

Clerides, S.K., Lach, S. and Tybout J.R. 1998. Is Learning By Exporting Important? MicroDynamic Evidence from Colombia, Mexico, And Morocco. The Quarterly Journal of Economics, 113(3), 903-947 (MIT Press).

Delapierre, M., Madeuf, B. and Savoy, A. 1998. NTBFs: the French case. Research Policy, 26, 989-1003.

Eriotis, N., Frangouli, P. and Ventoura-Neokosmides, Z. 2002. Profit margin and capital structure: an empirical relationship. Journal of Applied Business Research, 18(2), 85-88.

Ferguson, R., Olofsson, C. 2004. Science parks and the development of NTBFs: location, survival and growth. Journal of Technology Transfer, 29, 5-17.

Filatotchev, I., Liu, X., Buck, T. and Wright, M. 2009. The Export Orientation and Export Performance of High-Technology SMEs in Emerging Markets: The Effects of Knowledge Transfer by Returnee Entrepreneurs. Journal of International Business Studies.

Giudici, G. and Paleari, S. 2000. The provision of finance to innovation: a survey conducted among Italian technology-based small firms. Small Business Economics, $14,37-53$.

Greenaway, D. and Kneller R. 2005. Exporting and Productivity: Theory, Evidence and Future Research. Singapore Economic Review, 50, 303-312.

Greenaway, D. and Yu Z. 2004. Firm-level Interactions between Exporting and Productivity: Industry-Specific Evidence. Review of World Economics, 140(3), 376-392.

Kafouros, M. 2005. R\&D and productivity growth: evidence from the UK. Economics of Innovation and New Technology, 14(6), 479-97.

Lawless, M. 2009. Firm-Level Interactions between Exporting and Productivity: IndustrySpecific Evidence Firm, export dynamics and the geography of trade. Journal of International Economics, 77, 245-254.

Liargovas, P.G. and Scandalis, K.S. 2008. Export motivations and barriers: a case study of Greek firms exporting to four south-eastern European countries. Global Business and Economic Review, 10(4), 430-48.

Liapis, K., Rovolis, A., Galanos, C. and Thalassinos, I.E. 2013. The Clusters of Economic Similarities between EU Countries: A View Under Recent Financial and Debt Crisis. European Research Studies Journal, 16(1), 41-66.

Makris, I. 2007. Innovative process and firm's performance: a survey in traditional and high-tech sectors of Greek economy. Global Business and Economics Anthology, 2, 117-24.

Nikolaidis, V., Makris, I. and Stavroyiannis, S. 2009. Prediction of exporting ability using company characteristic data. Proceedings of International Conference on Applied Economics 2009, 469-76.

Sjöholm, F. 1999. Do Foreign Contacts Enable Firms to Become Exporters? Working Paper Series in Economics and Finance 326 (Stockholm School of Economics).

Thalassinos, I.E., Ugurlu, E. and Muratoglu, Y. 2012. Income Inequality and Inflation in the 
EU. European Research Studies Journal, 15(1), 127-140.

Thalassinos, I.E. and Politis, D.E. 2012. The evaluation of the USD currency and the oil prices: A VAR Analysis. European Research Studies Journal, 15(2), 137-146.

Thalassinos, I.E., Hanias P.M. and Curtis G.P. 2012. Time series prediction with neural networks for the Athens Stock Exchange indicator. European Research Studies Journal, 15(2), 23-31.

Voudouris, I., Lioukas, S., Makridakis, S. and Spanos, Y. 2000. Greek Champions: Lessons from Small, Little-Known Firms in Greece. European Management Journal, 18(6), 663-74.

Voulgaris, F., Papadogonas, T., Agiomirgianakis, G. 2005. Job creation and job destruction in Greek manufacturing. Review of Development Economics, 9(2), 289-301. 